Published as Chapter 1 in 'Transport, Travel and Later Life' edited by Charles Musselwhite, and published by Emerald Publishing, Bingley, UK, in 2017.

\title{
Older people's travel and its relationship to their health and wellbeing
}

Roger Mackett

Centre for Transport Studies

University College London

\section{Abstract}

As people age they tend to do more local journeys, shown by a lower mean trip length, from around 50 years onward. One reason for this is increased difficulty with mobility as people age; around onethird of those aged over 70 have mobility difficulties. Physiological changes in later life that have consequences for travel include deterioration of hearing and seeing, decreased skeletal muscles and reduced mobility of joints. Another reason for the decrease seen in many western countries is retirement from work, with many fewer trips made for commuting purposes. However, there are increases in shopping, personal business and leisure trips when commuting is reduced. That said, older people would still like to make more discretionary journeys in later life, especially to visit family and friends more often. A review of literature suggests how important mobility is for wellbeing through social interaction and being involved in activities outside the home.

Keywords: Travel, health, wellbeing, transport statistics, active transport, public transport

\section{Introduction}

Travel is an essential element of everyday life, enabling people to work to obtain money to purchase goods and services, to receive education to enhance their knowledge and skills, to go to the shops, to interact with others to undertake leisure activities and to contribute to society and so on. As people move through the life cycle their travel patterns change. The purpose of this chapter is to establish the factors that influence travel by older people, and to examine how travel affects their lives.

In the next section, changes in the total volume of travel by age and the effects of impairments and lifestyle on this are examined. The implications of travel for wellbeing including maintaining independence are then considered. After examination of the trips that older people would like to make but are not able to and why, individual modes of travel are discussed, including the difficulties posed by some modes for older people and the implications for their health and wellbeing.

Whilst the data are for the United Kingdom, similar trends in ageing can be observed in many other countries in Europe (Giannakouris, 2008) and elsewhere, so it is likely that the findings have widespread implications.

\section{Travel by older people}

Table 1 shows how the volume of travel varies with age in England. As children grow up they travel further, with the most travel being made by those aged 40 to 49 . After that age, people make fewer trips and travel less far. However, even those aged 70+ still make about two trips a day, but the trips 
are more local, as shown by the lower mean trip length. It can be seen that as people move beyond their fifties the number of trips only declines slightly, but the trips tend to be shorter. As people move beyond their sixties they make considerably fewer trips and travel much less far.

Table 1 Number of trips and total distance travelled per person in km by age in England in 2015

\begin{tabular}{llllllllll}
\hline & All ages & $\mathbf{0 - 1 6}$ & $\mathbf{1 7 - 2 0}$ & $\mathbf{2 1 - 2 9}$ & $\mathbf{3 0 - 3 9}$ & $\mathbf{4 0 - 4 9}$ & $\mathbf{5 0 - 5 9}$ & $\mathbf{6 0 - 6 9}$ & $\mathbf{7 0 +}$ \\
\hline $\begin{array}{l}\text { Number of } \\
\text { trips }\end{array}$ & 914 & 821 & 782 & 843 & 1021 & 1061 & 994 & 972 & 760 \\
$\begin{array}{l}\text { Total } \\
\text { distance }\end{array}$ & 10638 & 6806 & 8330 & 10698 & 12458 & 14285 & 13530 & 11608 & 7619 \\
$\begin{array}{l}\text { Mean trip } \\
\text { length }\end{array}$ & 11.6 & 8.3 & 10.7 & 12.7 & 12.2 & 13.5 & 13.6 & 11.9 & 10.0 \\
\hline
\end{tabular}

Source: Tables NTS0601 and NTS0605 in Department for Transport (2016).

One reason why people travel less as they age is increasing difficulty in being mobile, as indicated in Table 2. Some younger people have such difficulties, but the proportion increases significantly with age, so that about one third of those aged 70 and over have mobility difficulties. This affects trip making, as shown in Table 3. People of all ages with mobility difficulties make fewer trips than those without, but as people move beyond middle age the decline in the number of trips made is steeper.

Table 2 Percentage of people with or without mobility difficulties by age in England in 2015

\begin{tabular}{llllll}
\hline Mobility status & All aged 16+ & $\mathbf{1 6 - 4 9}$ & $\mathbf{5 0 - 5 9}$ & $\mathbf{6 0 - 6 9}$ & $\mathbf{7 0 +}$ \\
\hline With a mobility difficulty & 9 & 3 & 8 & 13 & 30 \\
No mobility difficulty & 91 & 97 & 92 & 87 & 70 \\
Total & 100 & 100 & 100 & 100 & 100
\end{tabular}

Source: Table NTS0622 in Department for Transport (2016).

Table 3 Trips per person per year by age and mobility status in England in 2015

\begin{tabular}{llllll}
\hline Mobility status & All aged 16+ & $\mathbf{1 6 - 4 9}$ & $\mathbf{5 0 - 5 9}$ & $\mathbf{6 0 - 6 9}$ & $\mathbf{7 0 +}$ \\
\hline With a mobility difficulty & 605 & $\mathbf{7 6 8}$ & 691 & $\mathbf{7 0 3}$ & 474 \\
No mobility difficulty & 968 & 961 & 1019 & 1014 & 859 \\
All & 935 & 955 & 995 & 972 & 760
\end{tabular}

Source: Table NTS0622 in Department for Transport (2016).

'Mobility difficulty' covers a variety of conditions because the ageing process can lead to a number of physiological changes which can have consequences for travel, for example deterioration of hearing and seeing, decreased skeletal muscles, reduced mobility of joints, reduced flexibility of ligaments, and reduced pulmonary elasticity and increasing stiffness of the thorax which can make breathing more difficult (Millonig et al., 2012). Travel requires both physical and mental abilities: the physical include walking, standing or pedalling a bicycle, the ability to board and alight from a bus or train, and to enter or leave a car and to control it. The mental abilities include the ability to remember information about the route, the ability to receive audio and visual information, the cognitive skills to 
process that information and take decisions, interpersonal communication skills to obtain tickets and information, and confidence in travelling. The percentages of population groups with various impairments are shown in Table 4. A whole range of impairments increase with age, with the proportion of people above the state pension age with the various impairments being about five times as high as that of working age adults. The impairment which affects the highest proportion of older people is lack of mobility, followed by lifting and carrying, possibly causing some older people to use the car rather than walking for shopping trips. Martin et al. (1988) show that $19.8 \%$ of those aged $60-$ 74 and $49.6 \%$ of those aged 75 and over have locomotion difficulties compared with $3.1 \%$ of those aged 16-59. The third highest category is manual dexterity, possibly caused by arthritis in some cases, which can affect the ability to manipulate coins and credit cards for ticket and car parking machines, and the fourth category is physical co-ordination. About ten million people in the UK have arthritis (Arthritis Care, 2014). Although it can affect people of any age, it is particularly common amongst older people. One cause is arthritis which is inflammation of the joints and causes pain and difficulty in moving around. It can it can cause loss of strength and grip which in turn may make movement more difficult. According to Martin et al. (1988), 5.4\% of those aged 60-74 in Britain and 14.9\% of those aged 75 and over have difficult reaching compared with $0.9 \%$ of those aged $16-59$.

Table 4 Percentage of population groups with impairments in 2010-11 (prevalence)

\begin{tabular}{lll}
\hline Impairment & State pension age adults & Working age adults \\
\hline Mobility & 30 & 5 \\
Lifting, carrying & 28 & 5 \\
Manual dexterity & 12 & 3 \\
Physical co-ordination & 11 & 2 \\
Communication & 8 & 2 \\
Continence & 7 & 1 \\
Memory, concentration and learning & 7 & 2 \\
Recognising when in danger & 2 & 1 \\
Other & 12 & 4 \\
\hline
\end{tabular}

Source: Office for National Statistics (2013a, b) and Department for Work and Pensions (2012).

Note: In Britain, the state pension age was 65 for men and 60 for women in 2010-11.

Table 4 shows that $8 \%$ of the people of state pension age have communication difficulties compared with $2 \%$ of working age adults. Around $1,000,000$ people in Britain have such impairments, for example a speech impairment, which may make communicating with bus drivers and ticket office staff difficult. Memory, concentration and learning impairments affect $7 \%$ of older people compared with $2 \%$ of working age adults. There are 835,000 people in the UK who have dementia of whom about 795,000 are aged over 65, with the total number projected to increase to over one million by 2021 and over two million by 2051 (Alzheimer's Society, 2014). 35\% of people with dementia only go out once a week or less and 10\% leave their home once a month or less (Alzheimer's Society, 2013).

Other impairments which can make going out difficult are visual and hearing impairments. Around 2 million people in Britain have sight loss (RNIB, 2014). Martin et al. (1988) found that $5.6 \%$ of those aged $60-74$ in Britain and $26.2 \%$ of those aged 75 and over have difficulty seeing, compared with $0.9 \%$ of those aged 16-59. Hearing loss affects more than 10 million people in the UK (Action on Hearing Loss, 2013). $11.0 \%$ of those aged $60-74$ in Britain and $32.8 \%$ of those aged 75 and over have difficulty hearing compared with $1.7 \%$ of those aged 16-59 (Martin et al., 1988). 
As well as the various conditions indicated above, many older people become increasing frail as they age. Frailty is a clinically-recognised condition resulting from a decline in the body's physical and psychological reserves leading to increased vulnerability (British Geriatrics Society, 2014). Gale et al. (2015) examined 5,450 people aged 60 and over from the English Longitudinal Study of Ageing. They found that the overall weighted prevalence of frailty was $14 \%$ with prevalence rising with increasing age, from $6.5 \%$ in those aged $60-69$ years to $65 \%$ in those aged 90 or over. Frailty occurred more frequently in women than in men (16\% compared with $12 \%)$. Mobility difficulties were very common: $93 \%$ of frail individuals had such difficulties compared with $58 \%$ of the non-frail individuals. Difficulties in performing instrumental activities of daily living were reported by $64 \%$ of frail individuals, compared with $15 \%$ of the non-frail individuals. Among those with difficulties with mobility or other daily activities, $71 \%$ of frail individuals and $31 \%$ of non-frail individuals said that they received help. Of those with difficulties, $63 \%$ of frail individuals and $20 \%$ of non-frail individuals used a walking stick, but the use of other assistive devices was uncommon.

Part of the reason for the decrease in travel as people grow older shown in Table 1 is because of changes in the reasons that trips are made, reflecting progress through the life-cycle. People in England tend to retire from full-time employment in England between the ages of 60 and 65 . This can be seen in Table 5 where the number commuting trips between the ages of 50-59 to 60-69 declines from 224 to 87 . However, the total number of trips made decreases by much less, suggesting that after retirement people make more of other types of trips. There are increases in shopping trips, personal business and all types of leisure trips. After the age of 70, the main types of trip made are shopping and personal business plus various types of leisure travel.

Table 5 Average number of trips (trip rates) per person by age and purpose in England in 2015

\begin{tabular}{lllll}
\hline Purpose & All ages & $\mathbf{5 0 - 5 9}$ & $\mathbf{6 0 - 6 9}$ & $\mathbf{7 0 +}$ \\
\hline Commuting & 142 & 224 & 87 & 8 \\
Business & 31 & 65 & 27 & 4 \\
Education & 62 & 1 & - & - \\
Escort education & 48 & 22 & 21 & 8 \\
Shopping & 177 & 220 & 281 & 289 \\
Other escort & 83 & 73 & 65 & 38 \\
Personal business & 89 & 96 & 124 & 131 \\
Visit friends at private home & 87 & 83 & 107 & 76 \\
Visit friends elsewhere & 47 & 52 & 61 & 54 \\
Sport / entertainment & 64 & 54 & 79 & 59 \\
Holiday / day trip & 39 & 46 & 56 & 44 \\
Other including just walk & 43 & 60 & 63 & 47 \\
All purposes & 914 & 994 & 972 & 760 \\
\hline
\end{tabular}

Source: Table NTS0611 in Department for Transport (2016).

Because commuting and business trips tend to be longer than most other types of trips, when people move from full time work to retirement, the overall distance they travel tends to decrease, as shown in Table 6. They are able to travel further for shopping and leisure trips, probably because they have more time available. 
It is interesting to note that some people aged 60 and over are making escort trips to education establishments. In many cases, this is probably grandparents taking their grandchildren to and from school, enabling the children's parents to work. Older people aged 60-69 make almost as many other escort trips as those aged 50-59. Some of these may be to take spouses and friends to medical appointments, or to take others who are no longer able to drive shopping or on personal business.

Table 6 Average total distance in km travelled per person by age and purpose in England in 2015

\begin{tabular}{lllll}
\hline Purpose & All ages & $\mathbf{5 0 - 5 9}$ & $\mathbf{6 0 - 6 9}$ & $\mathbf{7 0 +}$ \\
\hline Commuting & 2093 & 3274 & 1206 & 83 \\
Business & 997 & 1968 & 707 & 82 \\
Education & 542 & 5 & 2 & 2 \\
Escort education & 192 & 184 & 96 & 83 \\
Shopping & 1200 & 1578 & 2016 & 1896 \\
Other escort & 701 & 738 & 618 & 333 \\
Personal business & 733 & 947 & 1078 & 984 \\
Visit friends at private home & 1542 & 1773 & 2051 & 1450 \\
Visit friends elsewhere & 490 & 515 & 704 & 568 \\
Sport / entertainment & 803 & 824 & 869 & 686 \\
Holiday / day trip & 1494 & 1630 & 2144 & 1382 \\
Other including just walk & 106 & 96 & 115 & 72 \\
All purposes & 10638 & 13530 & 11608 & 7619 \\
\hline
\end{tabular}

Source: Table NTS0612 in Department for Transport (2016).

\section{The implications of travel for older people's wellbeing}

Travel facilitates engagement with others, enjoyment obtained from leisure activities and satisfaction from contributing to society. It can also provide the means to obtain healthcare and some forms of travel offer health-enhancing physical activity through walking and cycling. According to the Health White Paper 'Healthy Lives, Healthy People' (Department of Health, 2010) "Maintaining social networks, being part of a community and staying active all benefit health and wellbeing in later life". This means that the ability to travel is as important in later life as in childhood and middle-age. Banister and Bowling (2004) argue that there are six 'building blocks' of quality of life for the elderly. These include engaging in a large number of social activities and feeling supported, living in a neighbourhood with good community facilities and services (including transport, and feeling safe in one's neighbourhood. They suggest that these contribute more to perceived quality of life than material circumstance such as levels of income and social class. Spinney et al. (2009) found a significant association between transport mobility benefits and quality of life in their research into the quality of life for non-working elderly Canadians.

Banister and Bowling (2004) examined a survey of 1000 respondents aged 65+ in the ONS Omnibus Survey with an average age of 73 . They found a positive link between the number of social activities which require going out (and so travel) and the quality of life. The number of such social activities increased as the rating of local transport increased (that is, the better that local transport was perceived, the more social activities participated in). Those with higher quality of life made more contact with friends than those with lower values. 
It can be argued that mobility is an essential part of later life, because lack of it brings loss of independence (McInnes, 2011). Gabriel and Bowling (2004) carried out interviews with 999 older people in private households in Britain and found that the respondents regarded being able to walk and having good mobility as important to them as it helped them to retain independence which they saw as an important element of a good quality of life and enabled them to avoid dependence on others. However, Schwanen, Banister and Bowling (2012), using the results of 42 interviews with older people aged 70 and over, found that trips outside the home could imply either dependence (relying on others for lifts) or independence (when they could drive, walk or use buses or taxis).

Whilst, intuitively, there is a link between mobility and the quality of life, Metz (2000) argues that the relationship is ill defined, based on anecdotal evidence. He argues that five elements of mobility seem to be important: travel to achieve access to desired people and places, the psychological benefits of movement - 'getting out and about', the exercise benefits, involvement in the local community, and the potential to travel: knowing a trip could be made even if it is not actually undertaken.

The evidence cited above shows that making it easier for older people to travel produces various benefits, including improved quality of life and health. It may also help society by allowing older people to make a greater contribution. WRVS (2011) (now the Royal Voluntary Society) commissioned a study to estimate the economic contribution of older people to society, through spending in shops, voluntary work, looking after grandchildren while their parents work, and through taxes on expenditure and employment. It can be argued that making it easier for older people to travel would enable them to make an even greater contribution (Mackett 2015).

\section{The travel that older people would like to do}

In 2001, the Department for Transport (2001) published the results of a survey of 1445 people aged 60 and over about their travel needs, and the barriers that stop them travelling more. As Table 7 shows, the types of activities they would like to make more of are leisure and shopping trips, the types of trips that they already make. The principle barriers to making the journeys are divided into three types: direct transport or journey, mobility, sensory or health, and non-transport. The main type of barrier for each type of trip has been highlighted. Transport and journey barriers are the most important for the three types of activity that most people would like to do more of, namely visiting family and friends and meeting friends elsewhere. This is probably because the destination for many of these trips will be in the suburbs and rural areas, unlike many shopping and leisure trips. Trips to the suburbs and rural areas are usually fairly straightforward by car, but not by public transport. If older people are not able to travel by car, then such journeys are very difficult. If this is the case, the barriers are the lack of suitable transport. For shopping and post office trips the main barriers are mobility, sensory and health. The destinations for these trips are likely to be in shopping centres, and so served by public transport. Mobility, sensory and health barriers may be associated with the need to board or alight from buses, and walk to and from bus stops, which may involve crossing the road, walking up or down steps or gradients. These can present various barriers to older people. For trips to leisure and sport and to day care centres, the barriers tend to be non-transport, and so are at the destination, which may reflect poor access into and within buildings or unsuitable equipment or staff who are not able to provide suitable support. It is clear is that the main barriers that prevent older people enjoying the activities that they wish to attend are related to transport, including its absence for some journeys. This issue can be explored further by considering the modes of travel used by older people, as discussed in the next section. 
Table 7 Barriers to activities for people aged 60 and over

\begin{tabular}{|c|c|c|c|c|}
\hline & \multirow{2}{*}{$\begin{array}{l}\begin{array}{l}\text { Would like } \\
\text { to do more }\end{array} \\
\%\end{array}$} & \multicolumn{3}{|c|}{ Principal barrier preventing more trips being made } \\
\hline & & $\begin{array}{l}\text { Direct transport } \\
\text { or journey \% }\end{array}$ & $\begin{array}{l}\text { Mobility, sensory } \\
\text { or health \% }\end{array}$ & $\begin{array}{l}\text { Non- } \\
\text { transport \% }\end{array}$ \\
\hline Visit family & 12 & 58 & 18 & 24 \\
\hline Visit friends' homes & 10 & 46 & 27 & 25 \\
\hline $\begin{array}{ll}\text { Meet } & \text { friends } \\
\text { elsewhere } & \end{array}$ & 10 & 46 & 21 & 33 \\
\hline Leisure and sport & 8 & 15 & 24 & 57 \\
\hline Other shopping & 7 & 37 & 43 & 21 \\
\hline Food shopping & 6 & 33 & 50 & 16 \\
\hline Day centre visit & 2 & 25 & 30 & 45 \\
\hline Post Office & 2 & 40 & 42 & 19 \\
\hline $\begin{array}{l}\text { Visit others in } \\
\text { hospital }\end{array}$ & 1 & 65 & 23 & 13 \\
\hline
\end{tabular}

Source: Table 5.3 in Department for Transport (2001).

\section{How older people travel}

Turning to the modes of travel used by older travellers, it can be seen in Table 8 that the dominant mode is the car, particularly as a driver, even for those aged 70 and over. This is particularly the case when distance is considered, as shown in Table 9. Those aged 60-69 travel further by car than the average across the whole population and even those aged 70 and over make over $75 \%$ of their travel by car and almost half as car drivers.

Table 8 Average number of trips per person by age and mode in England in 2015

\begin{tabular}{lllll}
\hline Mode & All ages & $\mathbf{5 0 - 5 9}$ & $\mathbf{6 0 - 6 9}$ & $\mathbf{7 0 +}$ \\
\hline Walk & 200 & 174 & 178 & 139 \\
Bicycle & 17 & 17 & 17 & 5 \\
Car / van driver & 481 & 586 & 511 & 341 \\
Car / van passenger & 204 & 124 & 165 & 163 \\
Other private transport & 9 & 9 & 9 & 8 \\
Local and non-local buses & 62 & 44 & 65 & 82 \\
Rail & 29 & 30 & 17 & 8 \\
Taxi / minicab & 10 & 8 & 8 & 9 \\
Other public transport & 3 & 3 & 2 & 3 \\
All modes & 914 & 994 & 972 & 760 \\
\hline
\end{tabular}

Source: Table NTS0601 in Department for Transport (2016).

The bus is unique among the modes shown in that its use increases with age from 50 onwards, possibly partly because of the decrease in car use. Rail use declines with age, probably because much of its use is associated with commuting. Taxi use is low for each age group, but its use does not decline with age, with slightly more use for the $70+$ age group than the two immediately younger groups. 
Walking is second only to car use for all the age groups shown in terms of the number of trips, and does not decline until people reach the highest age group. Cycling is low for all the age groups and declines at high ages.

Table 9 Average total distance in $\mathrm{km}$ travelled per person per year by age and mode in England in 2015

\begin{tabular}{lllll}
\hline Mode & All ages & $\mathbf{5 0 - 5 9}$ & $\mathbf{6 0 - 6 9}$ & $\mathbf{7 0 +}$ \\
\hline Walk & 294 & 286 & 267 & 190 \\
Bicycle & 85 & 98 & 83 & 24 \\
Car / van driver & 5227 & 8654 & 6608 & 3515 \\
Car / van passenger & 3029 & 2389 & 2858 & 2478 \\
Other private transport & 205 & 234 & 197 & 216 \\
Local and non-local buses & 534 & 384 & 659 & 728 \\
Rail & 1096 & 1306 & 776 & 371 \\
Taxi / minicab & 88 & 112 & 77 & 62 \\
Other public transport & 83 & 64 & 83 & 32 \\
All modes & 10638 & 13530 & 11608 & 7619 \\
\hline
\end{tabular}

Source: Table NTS0605 in Department for Transport (2016).

Some of the changes in modal use with age reflect the change in the mix of trip purposes arising from lifestyle changes associated with retirement, for example, less rail use because rail is often used for commuting. However, there are barriers associated with individual modes as discussed above. More information is provided in Table 10 based on the results of the survey carried out in 2001 (Department for Transport, 2001). It may be noted that car driver does not appear as a mode, presumably because those older people who have a car to drive do not see any barriers to their use of it. Over $40 \%$ of those using each mode have a difficulty in doing so. The most common reason for the difficulty in all cases except train is accessibility which is associated with personal mobility and health problems. For train, the main barrier is affordability, followed by the nature of the journey. It is interesting that accessibility is a larger barrier to taxi use than affordability. Overall, accessibility is the biggest barrier, followed by other reasons, which covers a wide variety of issues, then the availability of the mode and the nature of the journey, followed by affordability. Concerns about safety come very low. 
Table 10 Proportion of people aged 60 and over that have difficulty using current modes

\begin{tabular}{|c|c|c|c|c|c|c|c|c|}
\hline & \multirow{2}{*}{$\begin{array}{l}\% \text { using } \\
\text { each } \\
\text { mode }\end{array}$} & \multirow{2}{*}{$\begin{array}{l}\% \text { that } \\
\text { would } \\
\text { have } \\
\text { difficulty }\end{array}$} & \multicolumn{6}{|c|}{ Reasons for difficulties with current modes } \\
\hline & & & $\begin{array}{l}\text { Afforda- } \\
\text { bility \% }\end{array}$ & $\begin{array}{l}\text { Availab- } \\
\text { ility \% }\end{array}$ & $\begin{array}{l}\text { Accessi- } \\
\text { bility \% }\end{array}$ & $\begin{array}{l}\text { Safety } \\
\%\end{array}$ & $\begin{array}{l}\text { Journey } \\
\%\end{array}$ & $\begin{array}{l}\text { Other } \\
\%\end{array}$ \\
\hline Bus & 37.6 & 56.9 & 8 & 12 & 38 & 4 & 18 & 20 \\
\hline $\begin{array}{l}\text { Car } \\
\text { passenger }\end{array}$ & 33.5 & 53.0 & 5 & 29 & 38 & 1 & 8 & 19 \\
\hline Walk/cycle & 19.7 & 41.9 & - & - & 40 & 6 & 16 & 38 \\
\hline Taxi & 15.0 & 65.4 & 24 & 6 & 44 & 3 & 4 & 20 \\
\hline Train & 3.5 & 53.1 & 33 & 6 & 8 & - & 32 & 21 \\
\hline Tram/tube & 2.8 & 44.0 & 9 & - & 56 & 3 & 23 & 9 \\
\hline $\begin{array}{l}\text { Door-to- } \\
\text { door }\end{array}$ & 2.5 & 60.9 & 7 & 13 & 36 & 13 & 5 & 27 \\
\hline $\begin{array}{l}\text { Wheelchair/ } \\
\text { shopmobility }\end{array}$ & 1.5 & 64.3 & - & 8 & 65 & - & 6 & 22 \\
\hline $\begin{array}{l}\text { Taxi } \\
\text { subsidised }\end{array}$ & 1.0 & 44.4 & - & - & 63 & - & 19 & 19 \\
\hline Total & & 56.4 & 10 & 16 & 40 & 3 & 12 & 19 \\
\hline
\end{tabular}

Source: Table 5.5 in Department for Transport (2001).

Note: The percentages are proportions of total responses for each mode.

\section{Car travel}

For older people, car driving represents a symbol of freedom, independence and self-reliance, and having some control over life while poorer mobility without a car places a substantial burden on the individual, family, community and society (Whelan et al., 2006). Banister and Bowling (2004) found that people with access to a car had a more positive quality of life rating than those without. Those with access to the car were consistently more likely to participate in more social activities. Car access seemed to be a stronger indicator of out-of-home social activity participation than the rating given to local transport.

In order to drive a car, it is necessary to hold a driving licence following passing the driving test. In the UK, a car driving licence is held until the age of 70. From that age it is necessary to renew it every three years. Some older people choose not to renew their licences whilst others may be required to give up driving because they are no longer safe to drive. Table 11 shows the percentage of the population who hold a licence. Generally, licence holding increases with age, and then decreases. There are three effects going on here: the levels are lower at younger ages because not everyone choses to drive from the age of 17 , so there is a cumulative effect. At the upper end of the age range, some people cease to hold a licence because they no longer wish to drive or they have been prevented from doing so on health grounds. The third effect arises because levels of licence holding have increased over time: this is illustrated in Table 12. In 1975/76, levels of licence holding were much lower for all age groups than they were in $1985 / 86$. For people aged over 40, it grew in each time period after that, but with the decline in older ages discussed above. 
Table 11 Full car driving licence holders by age and gender in England in 2015

\begin{tabular}{lllllllll}
\hline & All aged 17+ & $\mathbf{1 7 - 2 0}$ & $\mathbf{2 1 - 2 9}$ & $\mathbf{3 0 - 3 9}$ & $\mathbf{4 0 - 4 9}$ & $\mathbf{5 0 - 5 9}$ & $\mathbf{6 0 - 6 9}$ & $\mathbf{7 0 +}$ \\
\hline Men & 80 & 33 & 67 & 81 & 88 & 90 & 90 & 81 \\
Women & 68 & 32 & 61 & 74 & 80 & 78 & 73 & 50 \\
All & 74 & 33 & 64 & 78 & 84 & 84 & 81 & 64 \\
\hline
\end{tabular}

Source: Table NTS0201 in Department for Transport (2016).

For each age group, in each year shown, more men hold a licence than women, but there has been a dramatic growth in the number of older women who hold a licence particularly over the age of 70, where the level grew from 4\% in 1975/76 to 50\% in 2015. This is because in 2015 more women had passed the driving test when they were younger than in earlier years, plus the growth in car ownership related to the general increase in prosperity. Back in the 1950s and 1960s, very few households owned more than one car, and in those households that owned a car, the adult male drove it. As motoring became cheaper and more women became employed, multiple car ownership grew. This effect now means that about half the females aged 70 or over have a licence to drive. However, it is noticeable that the decline in licence holding in later life is much steeper for women than men. This is partly because women tend to live longer than men so there are many more women than men aged 70 and over and their average age is higher.

Table 12 Full car driving licence holders by age and gender in England

\begin{tabular}{lllllllll}
\hline & All aged 17+ & $\mathbf{1 7 - 2 0}$ & $\mathbf{2 1 - 2 9}$ & $\mathbf{3 0 - 3 9}$ & $\mathbf{4 0 - 4 9}$ & $\mathbf{5 0 - 5 9}$ & $\mathbf{6 0 - 6 9}$ & $\mathbf{7 0 +}$ \\
\hline All & & & & & & & & \\
$1975 / 76$ & 48 & 28 & 59 & 67 & 60 & 50 & 35 & 15 \\
$1985 / 86$ & 57 & 33 & 63 & 74 & 71 & 60 & 47 & 27 \\
$1995 / 97$ & 69 & 44 & 74 & 82 & 82 & 76 & 64 & 39 \\
2005 & 72 & 31 & 65 & 82 & 84 & 83 & 75 & 52 \\
2015 & 74 & 33 & 64 & 78 & 84 & 84 & 81 & 64 \\
\hline & & & & & & & & \\
\hline Males & & & & & & & & \\
$1975 / 76$ & 69 & 36 & 78 & 85 & 83 & 75 & 58 & 32 \\
$1985 / 86$ & 74 & 37 & 73 & 86 & 87 & 81 & 72 & 51 \\
$1995 / 97$ & 82 & 51 & 81 & 90 & 89 & 89 & 83 & 65 \\
2005 & 81 & 36 & 68 & 86 & 90 & 91 & 88 & 74 \\
2015 & 80 & 33 & 67 & 81 & 88 & 90 & 90 & 81 \\
\hline & & & & & & & & \\
\hline Females & & & & & & & & \\
$1975 / 76$ & 29 & 20 & 43 & 48 & 37 & 24 & 15 & 4 \\
$1985 / 86$ & 41 & 29 & 54 & 62 & 56 & 41 & 24 & 11 \\
$1995 / 97$ & 58 & 36 & 68 & 74 & 74 & 63 & 46 & 22 \\
2005 & 64 & 26 & 61 & 77 & 79 & 75 & 62 & 36 \\
2015 & 67 & 32 & 61 & 74 & 80 & 78 & 73 & 50 \\
\hline
\end{tabular}

Figures prior to 1989 are for Great Britain, rather than England only.

Figures prior to 1995 are based on unweighted data

Source: Table NTS0201 in Department for Transport (2016). 
As discussed above, some older people cease driving, either voluntarily or because they are regarded as unsafe. Musselwhite and Haddad (2010) examined the travel needs of older people by conducting three focus groups with 26 current car drivers aged 68 to 90 years old and then interviews with 31 older ex-drivers aged 65 to 92 years old. They found that ceasing to drive caused many changes in travel behaviour, including anxiety about being able to go shopping and to hospital, and to attend doctors' surgeries, with respondents mentioning feelings of depression and annoyance, particularly amongst those 'forced' to give up driving following advice from others or a driving incident. Isolation and exclusion from society were mentioned as resulting feelings. It is possible to mitigate the effects of driving cessation by engaging in pre-planning the process of ceasing to drive (Musselwhite and Shergold, 2013).

Once people have ceased to drive they have to find alternative ways of meeting needs previously met through driving. In a New Zealand study, Davey (2007) interviewed 28 couples and 43 single people with an average age of 84.5 for men and 81.4 for women who had all been without private transport for at least six months. They coped in various ways, with the 'serious' transport requirements often being provided by alternative means, but many of the discretionary trips that contribute to the quality of life had been lost. Other problems included not being able to get to special occasions such as funerals and reunions, the unreliability of taxis which do not turn up, erratic bus services, missed opportunities such as access to sales in the shops, fresh fruit and vegetables, and the opportunity to shop at a leisurely pace and make comparisons. For some of them, visits to friends and relations were replaced by them visiting the person. Some people had home deliveries from supermarkets or by friends and relatives and bought clothes from catalogues. This means that at least some of their needs were met, but they missed the social contact and stimulation of leaving home and the physical activity.

In some cases it is possible for people who have been advised to cease driving to refuse to do so. In a study carried out in isolated communities in the United States, Johnson (2002) carried out 45 interviews with people aged 71.1 to 91.4 who had all had been advised to cease driving but had decided to continue to do so. The older people refused to believe that they were unsafe, they valued their independence and feared isolation if they could not drive.

\section{Public transport}

Older people in Britain are offered a number of concessions to use public transport. Usually this is in the form of a card that offers travel at a reduced price or free of charge, often in the off-peak.

Public transport can make a significant contribution to the quality of life of older people. Gabriel and Bowling (2004) interviewed 80 older people and found that good public transport was mentioned as contributing to the quality of life of 31 of the respondents. Positive factors mentioned included free bus-passes or discounted fares for older people, comfortable buses with a drop-step to make getting on and off easier, and having a regular and reliable service. Poor public transport was mentioned as having a negative effect on the quality of life of 26 respondents. Factors mentioned included uncomfortable buses, walking distance to bus stops, difficulty getting on and off buses, particularly older ones, and expensive journeys, even with discounts.

In the United Kingdom everybody who reaches the state pension age for women can obtain a concessionary travel pass (CTP) allowing free off-peak bus travel often with some locally-funded extensions such as travel in the morning peak or local rail travel (Mackett 2013, 2014a). The policy has been successful in achieving its aims of increasing public transport usage by older people, improving 
their access to services and increasing social inclusion (Mackett, 2014b). One third of the bus trips in England are now made free because of concessionary travel passes (CTPS) most of which are held by older people. Nearly $80 \%$ of those eligible for a CTP on the grounds of age have one (Department for Transport, 2016). The main reason that some people do not have a pass is that they have access to a car, either one they can drive themselves or as a car passenger (Humphrey and Scott, 2012). The takeup of passes tends to be lower for those with mobility difficulties than those without (Humphrey and Scott, 2012).

Over recent years, older people have increased their frequency of bus use. Prior to the introduction of free local bus travel nationally in 2006, about $30 \%$ of those aged 60 or over used the bus at least once a week (Department for Transport, 2016). This rose to $40 \%$ by 2010 . Conversely, the proportion that never travel on a bus fell from about $46 \%$ to $32 \%$, suggesting that offering CTPs has induced some older people who did not travel by bus to do so.

CTPs offer a number of benefits to older people, including access to recreation and leisure facilities (Hirst and Harper, 2011; Kelly, 2011), reduced social isolation (Andrews et al, 2012), better physical and mental health (Transport Scotland, 2009; Webb et al. 2012; Whitley and Prince, 2005), ease of driving cessation (Andrews, 2011; Hill et al., 2009) and improved quality of life (Andrews, 2011; Jones et al., 2013; Rye and Mykura, 2009).

In some places the population density is too low to make conventional bus services viable. In these areas, community transport often has a useful role to play. This is transport, often using minibuses, with volunteer drivers which provide a service to meet a community need including for many older passengers. Funding comes from the fares paid and sometimes from local authorities. Volunteer drivers using their own cars are another type of community scheme. For example, the Volunteer Driving Service operated by the Retired Senior Volunteer Programme (RSVP) North East uses older drivers to offer transport to people who need to attend health appointments and collect repeat prescriptions. There are similar schemes all over the country (Community Service Volunteers, 2007). Another type of service is Dial-a-Ride, which provides free door-to-door transport service for disabled people who cannot use conventional public transport. The service is provided by minibuses, taxis, people carriers or cars. The services have to be booked in advance, typically the day prior to travel. The service in London has been operating for over thirty years (Transport for London, 2014). One of the grounds for eligibility for the scheme in London is being aged 85 or over. The other grounds are based on various aspects of disability or eligibility for various benefits.

People aged 60 or over in Great Britain are eligible to buy a Senior Railcard for $£ 30$ a year. This entitles the holder to a saving of $1 / 3$ on Standard and First Class rail fares throughout Great Britain. The only travel not included is during the morning peak period, Monday to Friday (excluding public holidays) for journeys are made wholly within London and South East England (National Rail, 2014a).

'Passenger assist' is a scheme in which passengers who need assistance boarding or alighting from trains can request assistance, for example, those with a mobility or other disability that makes getting on and off trains difficult including many older people (National Rail, 2014b).

An important way of buying travel tickets and obtaining information about routes and public transport timetables is through the internet. Whilst many older people will have used computers in their employment, and some will have learnt in later life for communicating with family and friends, some will not. Others may have used it earlier in life but be no longer able to do so, because of deteriorating 
health, for example, difficulties in reading the screen or using the keyboard. As Table 14 shows, use of the internet decreases with age from over $80 \%$ use when people are in their fifties to well under half after the age of 75 . It is worth noting that even amongst the younger age groups in the table, computer use is not universal, and that quite a large proportion of those over the age of 80 , particularly men, are still using the internet and email. Internet usage is lower for women than for men for all age groups, and declines more rapidly at higher ages.

Table 14 Use of internet and/or email by age and sex in 2012-13

\begin{tabular}{lllllllll}
\hline & $\mathbf{5 2 - 5 4}$ & $\mathbf{5 5 - 5 9}$ & $\mathbf{6 0 - 6 4}$ & $\mathbf{6 5 - 6 9}$ & $\mathbf{7 0 - 7 4}$ & $\mathbf{7 5 - 7 9}$ & $\mathbf{8 0 +}$ & Total \\
\hline Men & 91.7 & 87.6 & 83.5 & $\mathbf{7 4 . 4}$ & 58.5 & 47.0 & 36.0 & $\mathbf{7 3 . 7}$ \\
Women & 85.6 & 85.1 & 77.3 & 67.9 & 53.4 & 35.3 & 15.3 & 63.8 \\
\hline
\end{tabular}

Source: Table S3a in Banks et al. (2014).

\section{Active travel}

Most journeys involve walking, for example to the bus stop or from the car park. Many journeys involve standing, for example whilst waiting at the bus stop or on the bus. According 'Inclusive Mobility' (Department for Transport, 2005), standing is difficult and painful for some people, particularly those with arthritis, rheumatism and back problems which are often associated with older people. Walking provides various benefits for older people, including preventing a decline in health-related quality of life (Choi et al., 2013), increased life expectancy and lower risk of Alzheimer's disease (Small et al., 2006). Walking offers the opportunity to meet people and socialise, including chance encounters with friends and new places, escape from indoors or from routine places and to enhance good feelings or positive experiences such as from the countryside. Banister and Bowling (2004) found that those who could walk 400 metres tended to report better quality of life than those who could not.

Walking is important both as a means of local transport and as a form of exercise. As Tables 8 and 9 show, those aged 60-69 walk more than aged 50-69, but less as they age further. This ageing effect is illustrated in Table 15 which shows how walking speed decreases with age. This not only means that they are not able to reach such a wide range of shops and leisure facilities, but may have implications for their safety as they may not be able to cross the road in sufficient time before the pedestrian lights turn to red (Asher et al., 2012).

Table 15 Mean walking speed (m/s) by age and sex, 2012-13

\begin{tabular}{lllllll}
\hline & $\mathbf{6 0 - 6 4}$ & $\mathbf{6 5 - 6 9}$ & $\mathbf{7 0 - 7 4}$ & $\mathbf{7 5 - 7 9}$ & $\mathbf{8 0 +}$ & Total \\
\hline Men & 1.01 & 0.97 & 0.92 & 0.83 & 0.71 & 0.92 \\
Women & 0.96 & 0.92 & 0.85 & 0.78 & 0.61 & 0.85 \\
\hline
\end{tabular}

Source: Table H4a in Banks et al. (2014).

There are some barriers to walking for older people: poorly kept pavements, lack of public conveniences and lack of benches, busy roads and difficulties crossing the road (Musselwhite and Haddad, 2010). Certain street attributes can make it easier for older people to walk, including provision, maintenance, ease of use, comfort, safety, protection and enjoyment (Newton et al., 2010).

Tables 9 and 10 show that very few older people in Britain travel by bicycle. Work in Canada found that barriers to cycling for older people included fears about sharing the road with cars, personal safety because of interactions with pedestrians and other cyclists, and concern about bicycle theft 
(Winters et al., 2015). One possibility for older people is use of the electric bicycle. Research in Australia has found that take-up of electric bicycle was often associated with lifestyle changes associated with retirement, for example, moving to a hilly area (Johnson and Rose, 2015). Carrying loads and dress for the destination were among the benefits of electric bikes.

Mobility scooters offer older people with mobility difficulties a means of getting out of the house. They are a relatively recent innovation. RICA (2014) has estimated that there are about 350,000 users of mobility scooters in the United Kingdom, with annual sales of about 80,000 vehicles and annual growth rates of $5-10 \%$. In the RICA survey, $74 \%$ of respondents said that they could not have made the same journeys if they did not have their mobility scooters. Mobility scooters appear to have a positive impact on the lives of their users (Thoreau, 2015).

\section{Conclusions}

In this chapter, it has been shown that volumes of travel vary throughout the life cycle. Two major factors influence older people's travel: many older people have completed their full-time education and employment, so that they have more time available for leisure activities and the travel that they generate, and secondly, their faculties are declining which affects their ability to travel.

Evidence suggests that key factors in the quality of life are the ability to participate in a large number of social activities, the ability to access good quality community facilities and services and being independent. These factors require mobility which transport provides. Whilst good quality public transport, walking and cycling facilities all contribute to this, the key factor in mobility is access to a car. A major issue for many older people is that, as they age, some of them are no longer able to drive, either because they realise that they no longer have the mental or physical faculties to do so, or because they are no longer permitted to do so. This can lead to feelings of anxiety because of the feelings of isolation and exclusion that it engenders. Giving up driving means that older people have to find alternative ways of meeting the needs that car travel facilitated such as shopping, but there may well be a loss of discretionary trips such as visiting friends and relatives. These are the types of trips that older people would like to make more of. The barriers to doing so, apart from no longer being able to drive in some cases, are accessibility issues to do with boarding and alighting from vehicles, health problems and the attitudes of staff.

The ability to travel has a significant impact on older people's independence, which in turn can affect their health. Travel has impacts on older people's health through physical activity from walking and cycling and better mental health through social interaction and being involved in activities outside the home. For these reasons, there is a good case for improving accessibility for older people so that they can enjoy healthy lives and contribute more to society.

\section{References}

Action on Hearing Loss (2013) Annual Report and Financial Statements for the year end 31 March 2013, available from http://www.actiononhearingloss.org.uk/ /media/Documents/Corporate\%20planning\%20and\%20bu siness\%20analysis/Annual Report and Accounts 2012 13.ashx.

Alzheimer's Society (2013) Building dementia-friendly communities: A priority for everyone, available from http://www.alzheimers.org.uk/site/scripts/download info.php?downloadID=1236. 
Alzheimer's Society (2014) Dementia 2014: Opportunity for change, available from http://www.alzheimers.org.uk/site/scripts/download info.php?filelD=2317.

Andrews $\mathrm{G}$ (2011) Just the ticket? Exploring the contribution of free bus fares policy to quality of later life: $A$ thesis submitted in partial fulfilment of the requirements of the University of the West of England, Bristol for the degree of Doctor of Philosophy.

Andrews G, Parkhurst G, Susilo Y O and Shaw J (2012) The grey escape: investigating older people's use of the free bus pass, Transportation Planning and Technology, 35 (1), 3-15.

Arthritis Care (2014) About arthritis, available from http://www.arthritiscare.org.uk/AboutArthritis.

Asher L, Aresu M, Falaschetti E, and Mindell J (2012) Most older pedestrians are unable to cross the road in time: a cross-sectional study, Age and Ageing, 41 (5), 690-694.

Banister D and Bowling A (2004) Quality of life for the elderly: the transport dimension, Transport Policy, 11(2), 105-115.

Banks J, Nazroo J and Steptoe A (eds) (2014) The Dynamics of Ageing: Evidence from the English Longitudinal Study of Ageing 2002-2012 (Wave 6), The Institute for Fiscal Studies, London WC1E 7AE, available from

http://www.elsaproject.ac.uk/uploads/elsa/docs w6/ELSA\%20Wave\%206\%20report.pdf.

British Geriatrics Society (2014) Fit for Frailty, available from http://www.bgs.org.uk/campaigns/fff/fff short.pdf.

Choi M, Prieto-Merino D, Dale C, Nüesch E, Amuzu A, Bowling, A, Ebrahim S and Casa J P (2013) Effects of changes in moderate or vigorous physical activity on changes in health-related quality of life of elderly British women over seven years, Quality of Life Research, 22, 2011-2020.

Community Service Volunteers (2007) Retire into Action: Retired and Senior Volunteer Programme, available from http://www.csv-rsvp.org.uk/site/home.htm.

Davey J A (2007) Older people and transport: coping without a car, Ageing and Society, 27 (1) 49-65. Department for Transport (2001) Older Drivers: A literature review, available from: www.dft.gov.uk/pgr/roadsafety/research/rsrr/theme3/olderdriversaliteraturerevie4770.

Department for Transport (2005) Inclusive mobility: A guide to best practice on access to pedestrian and transport infrastructure, available from https://www.gov.uk/government/publications/inclusivemobility.

Department for Transport (2016) National Travel Survey, available from http://www.dft.gov.uk/statistics/series/national-travel-survey/.

Department for Work and Pensions (2012) Family Resources Survey, United Kingdom, 2010/11, National Statistics, available from http://research.dwp.gov.uk/asd/frs/2010 11/frs 201011 report.pdf.

Department of Health (2010) Healthy Lives, Healthy People: Our strategy for public Health in England, HMSO, available from http://www.dh.gov.uk/prod consum dh/groups/dh digitalassets/documents/digitalasset/dh 1274 24.pdf.

Gabriel Z and Bowling A (2004) Quality of life from the perspectives of older people, Ageing and Society, 24(5), 675-691. 
Gale C, Cooper C and Sayer A A (2015) Prevalence of frailty and disability: findings from the English Longitudinal Study of Ageing, Age and Ageing, 44 (1), 162-5.

Giannakouris K (2008) Ageing characterises the demographic perspectives of the European societies,

Eurostat Statistics in Focus, 72/2008, available from
http://polennu.dk/sites/default/files/Eurostat\%20befolkningsprognose\%202008-2060.pdf

Hill K, Sutton L and Cox L (2009) Managing resources in later life: Older people's experience of change and continuity, Joseph Rowntree Foundation, available from http://www.jrf.org.uk/publications/managing-resources-later-life.

Hirst E and Harrop B (2011) Getting out and about: Investigating the impact of concessionary fares on older people's lives, Transport Action Group - Manchester, available from http://www.healthandtransportgroup.co.uk/health transport/Bus-Pass-Use-Qual-of-Life-

Final20110707.pdf.

Humphrey A and Scott A (2012) Older people's use of concessionary bus travel, report by NatCen Social Research for Age UK, available from http://www.ageuk.org.uk/documents/en-gb/forprofessionals/research/concessionary bus travel 2012.pdf?dtrk=true.

Johnson J E (2002) Why rural elders drive against advice, Journal of Community Health Nursing, 19 (4) 237-244.

Johnson $M$ and Rose $G$ (2015) Extending life on the bike: electric bike use by older Australians, Journal of Transport and Health, 2, 276-283.

Jones A, Goodman A, Roberts H, Steinbach R and Green J (2013) Entitlement to concessionary public transport and wellbeing: A qualitative study of young people and older citizens in London, UK, Social Science \& Medicine, 91, 202-209.

Kelly E (2011) A Ticket to Ride: Does Free Bus Travel Promote Active Ageing? Job Market Paper, University College London and Institute for Fiscal Studies, available from http://www.homepages.ucl.ac.uk/ uctpeke/Research files/A\%20Ticket\%20to\%20Ride\%20Sept\%20 2011.pdf.

Mackett R L (2013) Impact of concessionary bus travel on the wellbeing of older and disabled people, Transportation Research Record, issue 2352, 114-119.

Mackett R L (2014a) The impacts of concessionary travel passes for older and disabled people - a review of the evidence, Report produced as a contribution to the work of the CILT Concessionary Travel Group and the CILT Accessibility and Inclusion Forum, Chartered Institute of Logistics and Transport, available from www.bit.ly/concessionary.

Mackett R L (2014b) Has the policy of concessionary bus travel for older people in Britain been successful? Case Studies in Transport Policy, 2, 81-88.

Mackett R L (2015) Improving accessibility for older people - investing in a valuable asset, Journal of Transport and Health, 2, 5-13.

Martin J, Meltzer H and Elliot D (1988) The prevalence of disability among adults, OPCS Surveys of Disability in Great Britain, Social Survey Division, Office of Population Censuses and Surveys, HMSO, London.

McInnes L (2011) Importance of maintaining mobility to elderly health, Aging Health, 7 (2), 165-167. Metz D (2000) Mobility of older people and their quality of life, Transport Policy, 7 (2), 149-152. 
Millonig A, Mandl B, Lackner B, Massink R, van Buuren S, Perenboom R, Gorris T, Goldbohm S, Hoedemaeker M, Wilschut E, Wulf A, Henne S, Bencini G and Baldanzini N (2012) Profiles of Older People, Deliverable D2.1, GOAL Growing Older, staying mobile: Transport needs for an ageing society Collaborative Project, available from http://www.goal-project.eu/images/d2-1 final 20120725.pdf. Musselwhite C and Haddad H (2010) Mobility, accessibility and quality of later life, Quality in Ageing and Older Adults, 11 (1), 25-37.

Musselwhite $C$ and Shergold I (2012) Examining the process of driving cessation in later life, European Journal of Ageing, 10 (2) 89-100.

National Rail (2014a) Senior Railcard, available from http://www.senior-railcard.co.uk/.

National Rail (2014b) Information for disabled passengers, available from http://www.nationalrail.co.uk/stations destinations/disabled passengers.aspx\#TravelAssistance.

Newton R A, Ormerod M G, Burton E, Mitchell L and Ward-Thompson C (2010) Increasing independence for older people through good street design, Journal of Integrated Care, 18, 24-29.

Office for National Statistics (2013a) Revised Annual Mid-year Population Estimates, 2001 to 2010, available from http://www.ons.gov.uk/ons/dcp171778 345500.pdf.

Office for National Statistics (2013b) Pension Trends, Chapter 5: State Pensions, 2013 Edition, available from http://www.ons.gov.uk/ons/dcp171766 341468.pdf.

RICA (2014) Mobility scooters: a market study, Research Institute for Consumer Affairs, available from http://www.rica.org.uk/content/mobility-scooter-research.

RNIB (2014) Key information and statistics, Royal National Institute of Blind People, available from http://www.rnib.org.uk/knowledge-and-research-hub/key-information-and-statistics.

Rye T and Mykura W (2009) Concessionary bus fares for older people in Scotland - are they achieving their objectives? Journal of Transport Geography, 17, 451-456.

Schwanen T, Banister D and Bowling A (2012) Independence and mobility in later life, Geoforum, 43, 1313-1322.

Small G W, Silverman D H S, Siddarth P, Ercoll L M, Miller K J, Lavretsky H, Wright B C, Bookheimer S Y, Barrio J R and Phelps M E (2006) Effects of a 14-day healthy longevity lifestyle program on cognition and brain function, American Journal of Geriatric Psychiatry, 14, 538-545.

Spinney J E L, Scott D M and Newbold K B (2009) Transport mobility benefits and quality of life: A timeuse perspective of elderly Canadians, Transport Policy, 16, 1-11.

Thoreau R (2015) The impact of mobility scooters on their users. Does their usage help or hinder? A state of the art review, Journal of Transport \& Health, 2, 269-275.

Transport for London (2014) Dial-a-Ride, available from http://www.tfl.gov.uk/corporate/abouttfl/what-we-do/dial-a-ride.

Transport Scotland (2009) Evaluation of National Concessionary Travel in Scotland, carried out by the Halcrow Group Limited, Transport Research Series, Transport Scotland, available from http://www.scotland.gov.uk/Resource/Doc/272719/0081408.pdf.

Webb E, Laverty A, Mindell J and Millett C (2016) Free bus travel and physical activity, gait speed and adiposity in the English Longitudinal Study of Aging, American Journal of Public Health, 106, 136-142. 
Whelan M, Langford J, Oxley J, Koppel S and Charlton J (2006) The elderly and mobility: A review of the literature, Report number 255, Accident Research Centre, Monash University, Clayton, Victoria, Australia, available from http://monash.edu/miri/research/reports/muarc255.pdf.

Whitley R and Prince M (2005) Fear of crime, mobility and mental health in inner-city London, UK, Social Science \& Medicine, 61, 1678-1688.

Winters M, Sims-Gould J, Franke T and McKay H (2015) "I grew up on a bike": Cycling and older adults, Journal of Transport \& Health, 2, 58-67.

WRVS (2011) Gold Age Pensioners: Valuing the socio-economic contribution of older people in the UK, available from http://www.rovalvoluntaryservice.org.uk/our-impact/reports-and-reviews/goldage-pensioners. 